\title{
Evolution of phagocytic function in monocytes and neutrophils blood cells of healthy calves
}

\author{
Camila F. Batista, ${ }^{* 1}$ Maiara G. Blagitz, $†$ Heloisa G. Bertagnon, ${ }^{*}$ Renata C. Gomes, ${ }^{*}$ Kamila R. Santos, ${ }^{*}$ \\ and Alice M. M. P. Della Libera* \\ * Faculty of Veterinary Medicine and Animal Science, Department of Internal Medicine, University of São Paulo-FMVZ-USP, \\ Av. Prof. Dr. Orlando Marques de Paiva, 87, São Paulo 05508-270, SP, Brazil \\ †University of West of Santa Catarina (UNOESC), Campus II Xanxerê, Rodovia Rovilho Bortoluzzi SC 480 Km 3,5, Barro Preto, \\ 89820-000 Xanxerê, SC, Brazil
}

\begin{abstract}
The immune system of newborn calves is immature and must mature gradually. Understanding how this immunity is established may define different profiles. Twelve healthy calves were monitored during 8 time periods to assess the innate immune system during the first $90 \mathrm{~d}$. Blood samples were collected, and the blood phagocytes, identified by the expression of CD14 and CH138 surface molecules, were evaluated for phagocytic functionality (Staphylococcus aureus and Escherichia coli stained with propidium iodide) and the intracellular production of reactive oxygen species $\left(2,7^{\prime}\right.$-dichlorofluorescein diacetate oxidation). Functional changes in the CD14+ and CH138+ cells occurred at $40 \mathrm{~d}$ of age, with sporadic increases in phagocytosis intensity and reactive oxygen species production, and decreased phagocytosis occurred at $60 \mathrm{~d}$ of age. Therefore, fewer phagocytes were active from $40 \mathrm{~d}$ of age, although those that were active performed their roles with greater efficacy. That change presumably occurred because the calf phagocytes began to support the immune response without the influence of passive immunity. The animals failed to reach the stability needed to complete the maturation of the innate immune response by $90 \mathrm{~d}$ of age. These data are applicable for healthy calves only.
\end{abstract} Key words: phagocytosis, oxidative metabolism, flow cytometry, innate immunity, newborn calf

\section{INTRODUCTION}

Great advances have been made in the field of veterinary medicine, with a better understanding of diseases,

Received March 14, 2015.

Accepted August 29, 2015.

${ }^{1}$ Corresponding author: camilafb@usp.br new diagnostic methods, and new drugs. However, the calf-rearing stage continues to show high rates of morbidity and mortality, and septicemia, diarrhea, and pneumonia, as well as bovine babesiosis and anaplasmosis, remain the leading causes of mortality despite advances (Windeyer et al., 2014).

The hormonal changes in late pregnancy, including increased maternal and fetal cortisol, affect the innate immune response of newborn calves, causing a decrease in phagocytosis and in the bactericidal activity of neutrophils and macrophages. Furthermore, neonates show low levels of complement factors and a decrease in their activity, a decreased functional activity of natural killer cells, and a lower ratio of dendritic cells (Barrington and Parish, 2001; Morein et al., 2002; Chase et al., 2008).

At birth, naïve newborns are transferred from a sterile uterine environment to a septic environment. The immaturity of protective mechanisms and the time required to develop humoral and cell-mediated immune responses may account for their inability to initiate the immune response at birth (Barrington and Parish, 2001). At this stage, their immune response is primary and characterized by low concentrations of immunoglobulins (Cortese, 2009).

Few studies have evaluated the maturation of the cellular immune system in healthy calves from birth to puberty. Kampen et al. (2006) assessed lymphocyte subpopulations in calf blood from birth to 6 mo of age using flow cytometry. However, relatively little information has been reported regarding the characterization or roles of blood phagocytes. In a preliminary study, Batista et al. (2012) evaluated the local phagocytes in the calf respiratory system, showing the existence of variation in the functionality of these cells over time. To understand the development of cellular immunity in calves, the present study examined the immunophenotype and the function of blood phagocytes over the first 
3 mo of calf life to identify periods of increased disease susceptibility.

\section{MATERIALS AND METHODS}

The present study was approved by the Animal Ethics Committee of the School of Veterinary Medicine and Animal Science, University of São Paulo (Faculdade de Medicina Veterinária e Zootecnia da Universidade de São Paulo; FMVZ-USP). Twelve male Holstein calves, born of normal delivery, introduced into the study at 1 to $5 \mathrm{~d}$ of age were used. The total protein and $\gamma$-globulin of all the animals were $\geq 50$ and $10 \mathrm{~g} / \mathrm{L}$, respectively, which is indicative of the successful acquisition of passive immunity and animal health (Feitosa et al., 2001). The calves were allocated to the experimental neonatology center of the Clinic for Cattle and Small Ruminants at FMVZ-USP in individual iron cages suspended, measuring $1.40 \times 1.47 \times 0.72 \mathrm{~m}$, and after completing $30 \mathrm{~d}$ of life they were transferred to stalls measuring $1.375 \times 2 \mathrm{~m}$ with 2 calves per stall. During the day, the animals were released in a collective cemented place with incidence of sunlight. The animals were monitored daily to ensure their health during the study evaluated by blood count and by clinical examination. No abnormalities were found on clinical examination or in the blood count of these animals using reference parameters described by Peixoto et al. (2002). Nutritional management consisted of whole milk powder intake. They were given $4 \mathrm{~L}$ of milk per day, divided into 2 feedings. The animals were fed with pelleted feed for calves 2 times a day and ad libitum hay, water, and mineral salt. The serum immune function of these animals was evaluated during 8 intervals within the first 3 mo of life: first week of life (M1), 8 to $14 \mathrm{~d}$ old (M2), 15 to $22 \mathrm{~d}$ old (M3), 23 to $30 \mathrm{~d}$ old (M4), 31 to $40 \mathrm{~d}$ old (M5), 41 to $50 \mathrm{~d}$ old (M6), 51 to $60 \mathrm{~d}$ old (M7), and $90 \mathrm{~d}$ old (M8). The blood samples were collected by jugular venipuncture with vacuum method used in tubes with heparin.

Assays for population quantification, for the assessment of the intracellular production of reactive oxygen species (ROS) and for phagocytosis by blood leukocytes were performed using flow cytometry (Hasui et al., 1989; Kampen et al., 2004a,b). The blood cells were incubated with Staphylococcus aureus (ATCC 25923) or Escherichia coli (O98: H28) stained with propidium iodide (PI; catalog no. P4170, Sigma-Aldrich, St. Louis, $\mathrm{MO})$. The labeling of bacteria was performed as established by Hasui et al. (1989), with certain modifications (Souza et al., 2012).

The assays were performed in polypropylene tubes suitable for flow cytometry. To assess the basal intracellular ROS production, $100 \mu \mathrm{L}$ of blood from each ani- mal were added to each tube and incubated at $37^{\circ} \mathrm{C}$ for $30 \mathrm{~min}$ with $200 \mu \mathrm{L}$ of $0.3 \mathrm{mM} 2,7^{\prime}$-dichlorofluorescein diacetate (DCFH-DA). To conduct the phagocytosis tests, $100 \mu \mathrm{L}$ of $S$. aureus or E. coli stained with PI were added to those tubes in ratios bacteria to phagocytes of up to 25:1 [multiplicity of infection $(\mathbf{M O I})=25$ ].

The test to identify the blood phagocytes was performed together with the functional assessment. After centrifuging $\left(250 \times g\right.$ for $8 \mathrm{~min}$ at $\left.4^{\circ} \mathrm{C}\right)$ and discarding the supernatant, $1 \mu \mathrm{L}$ of mouse $\mathrm{IgG}_{1}$ anti-bovine CD14 monoclonal antibody (catalog no. MM61A, VMRD Inc., Pullman, WA) or $1 \mu \mathrm{L}$ of mouse IgM anti-bovine CH138 monoclonal antibody (catalog no. CH138A, VMRD Inc.) was added to the tubes according to the population to be identified, and the tubes were left standing at room temperature for $30 \mathrm{~min}$. After the incubation period, $1,000 \mu \mathrm{L}$ of ice-cold PBS were added, and then a new centrifugation $(250 \times g$ for $8 \mathrm{~min}$ at $4^{\circ} \mathrm{C}$ ) was performed. The supernatant was discarded, $1 \mu \mathrm{L}$ of goat anti-mouse IgG subscript 1 monoclonal secondary antibody conjugated to the fluorochrome allophycocyanin (catalog no. A10541, Invitrogen Corp., Carlsbad, CA) was added to the tubes to label the monocytes, and goat anti-mouse IgM monoclonal secondary antibody conjugated to allophycocyanin (catalog no. M31505, Invitrogen Corp.) was added to the tubes to identify granulocytes according to the manufacturer's recommendations. The tubes were kept at room temperature in the dark for $30 \mathrm{~min}$. An additional washing was performed and the samples were resuspended in $400 \mu \mathrm{L}$ of ice-cold PBS + BSA (0.1\%) and kept in the dark until they were read in a FACSCalibur flow cytometer (Becton Dickinson Immunocytometry Systems, San Diego, CA). The cytometer was connected to a computer with the software CellQuest (Becton Dickinson Immunocytometry Systems). The cells labeled with CD14 and CH138 were analyzed by fluorescence light (FL) 4, the bacteria stained with PI by FL3 and the ROS production by FL1, 100,000 events were acquired from each tube (total events), and the recorded data were analyzed using the software Flow Jo version 7.6.1 for Windows (Tree Star Inc., Ashland, OR).

Statistical analysis was performed using the statistical software GraphPad InStat version 3.01 (GraphPad Software Inc., San Diego, CA). The normality of the data distributions was assessed using the AndersonDarling test. The tests to assess the differences between the data means were performed using ANOVA for the data with a normal distribution or the Mann-Whitney $\mathrm{U}$ test for the data without a normal distribution. The differences were considered statistically significant when their probability was $<0.05$. 


\section{RESULTS AND DISCUSSION}

The motivations for understanding the defense mechanisms of calves are numerous and usually centered on the diversity of pathogens involved, the importance of the influence of different environmental factors (Coelho, 2009), the responsiveness to certain treatments, and the dependence on an adequate transfer of passive immunity (Koterba, 1993; Benesi, 1993; Feitosa, 2010). However, those studies do not focus on age, which can influence the functions of innate cells under basal conditions (i.e., in healthy animals that have adequate passive transfer).

The present study aimed to establish criteria for the inclusion and exclusion of samples that would provide reliable data on the immune system maturation without the effect of such factors as diseases, management, and individual characteristics. Thus, the assessment of changes in the activity of blood phagocytes could be performed following the longitudinal dynamics of the most important aspects of calf innate immune defenses, answering the question: does variation in the efficiency of the innate immunity parameters of calves occur with age during the first 3 mo of life?

A well-defined location for the distribution of the blood cell populations may be visualized in cytograms that divide the populations into granulocytes and monocytes according to the size and complexity of the leukocytes (Stieler et al., 2012; Figure 1). Immunophenotyping was performed based on that location using the CD14 cell surface molecule (Figure 1A), which is mainly expressed by monocyte-macrophage lineage cells (Taraktsoglou et al., 2011; Machugh et al., 2012; Hussen et al., 2013) in the monocyte cells gate, and the cell surface molecule CH138 (Figure 1B), which is expressed by the granulocytic cells of bovine blood (Tizard, 2012) in the granulocyte gate. No noticeable difference occurred in the percentage of those populations over time (Tables 1 and 2).

Phagocytosis is an innate immune defense mechanism, which is defined by the activation of complex signaling networks stimulated by contact with microorganisms (Perticarari et al., 1994; Underhill and Ozinsky, 2002). Phagocytic cells play a key role in the defense against infections, particularly bacterial infections. Phagocytosis and respiratory burst activity are 2 of the most important and essential functions of the innate immune defenses for the elimination of invading bacteria (Paape et al., 2003; Nauseef and Clark, 2015) and were assessed using ROS production and $S$. aureus and E. coli phagocytosis assays.

Escherichia coli and S. aureus labeled with PI acquired from a noncommercial source were used in the phagocytosis assay. Although this labeling method provides satisfactory results, the fluorescence intensity may vary between different label batches (Raidal et al., 1998), which was solved by labeling both bacteria simultaneously using the same batch of label and the same protocol.

An uninterrupted decrease in the percentage of $S$. aureus phagocytosis by CD14+ mononuclear cells was noted (Figure 1C). The percentage of cellular phagocytosis during the M1 age interval was higher than that during M2, M4, M6, M7, and M8 $(P=0.0010)$. The mean phagocytosis intensity values measured by the mean fluorescence intensity (MFI) showed no significant differences $(P=0.2174)$ among the age intervals.

That same assessment was performed for $\mathrm{CH} 138+$ granulocytic blood cells and showed no difference among the age intervals $(P=0.1421)$. However, in contrast with the results for the CD14+ cells, the CH138+ cells showed significantly different MFI for the $S$. aureus conjugate $(P=0.0025)$; the cellular phagocytosis intensity during M1 was higher than the intensities during M5 and M8, and the phagocytosis intensity during M2 was also higher than that during M8. Such differences were not observed for the other age intervals.

The results for $S$. aureus phagocytosis by CD14+ cells showed lower phagocytosis percentages from the fourth week until $90 \mathrm{~d}$ of age (M4 to M8). The large quantity of immunoglobulins from colostrum accounts for the immune system defense during the first month of life (C. F. Batista, unpublished data). The percentage of phagocytosis was high during the first $3 \mathrm{wk}$ of life (M1 to M3). This result is explained by the colostral cytokines, which, following absorption by the calf, migrate to the circulation and stimulate immune cell activity in all tissues (Ackermann et al., 2010). This phenomenon was observed by Batista et al. (2012) when studying these same functions in bronchoalveolar lavage cells of similarly aged calves.

Initially, in the present study, the CD14+ cells of the animals showed a reduced phagocytic capacity from the fourth week of life, and the CH138+ cells showed a reduction with increasing age. These patterns are consistent with a decline in colostral immunity at approximately 2 mo of life (M7), when this immunity decreased and the intensity of phagocytosis by the CD14+ and CH138+ cells increased, showing a greater efficacy by certain cells but not their maximum capacity. Such results corroborate the claim by Cortese (2009), who stressed that the maturation of the immune system of cattle does not occur before the fifth month of life. At this stage, the animals are able to respond to a pathogen, although the response is weaker, slower, and less efficient than that of animals with a mature immune system (Cortese, 2009). 
A

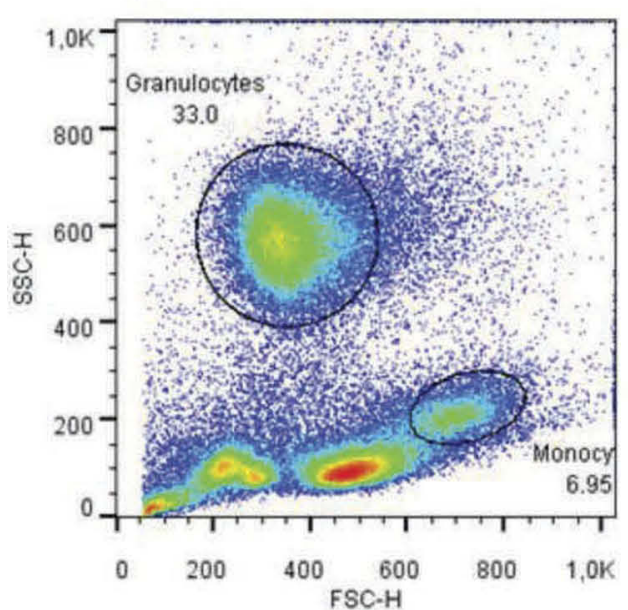

C

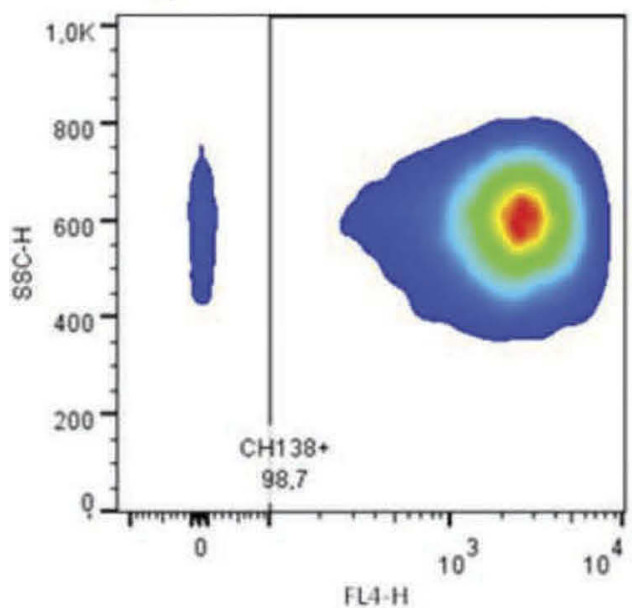

E

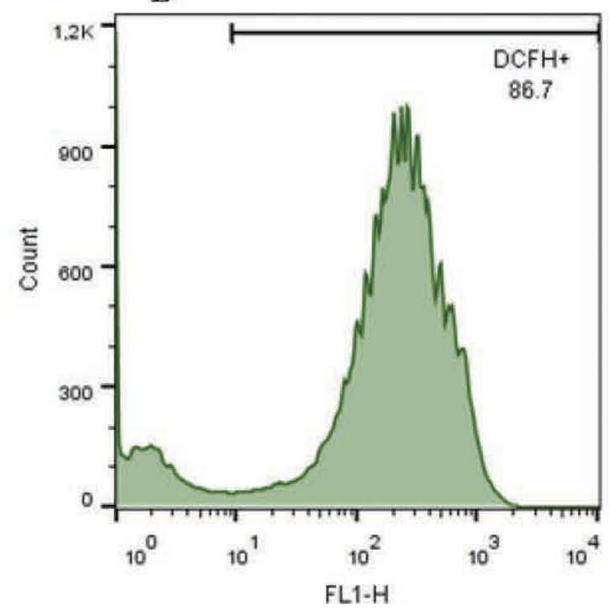

B

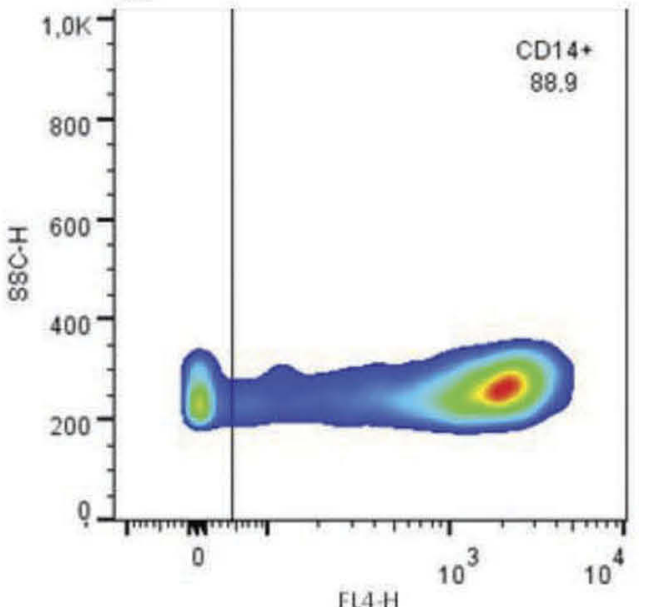

D

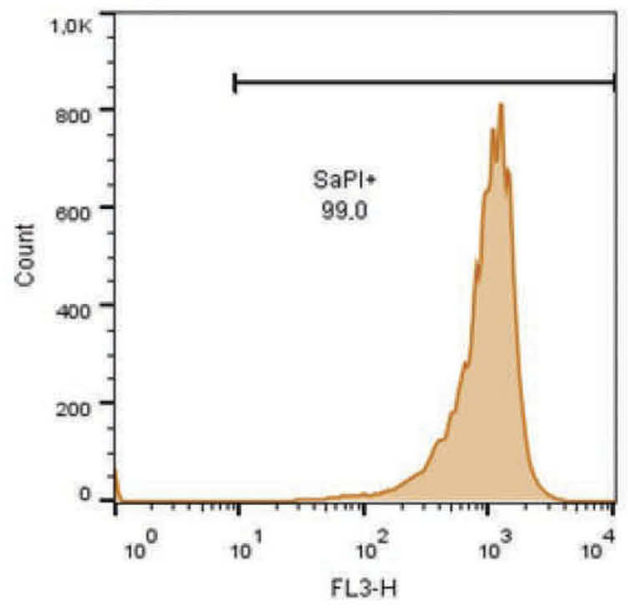

F

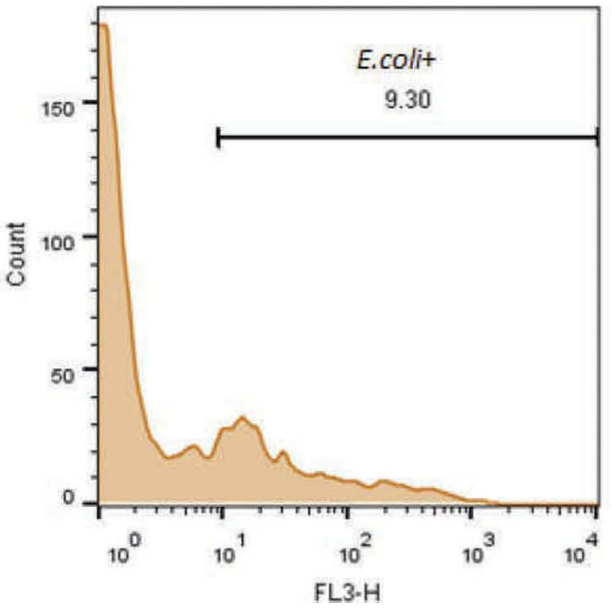

Figure 1. Examples of identification of the populations of calf blood phagocytes. Panel A indicates the cell selection in relation to leukocytes (SSC-H = side scatter light; FSC-H = forward scatter light). (B) Graphical representation of the population of monocytic cells labeled with CD14-allophycocyanin [APC; fluorescence light (FL) 4 emitted at a wavelength of $661 \pm 16 \mathrm{~nm}$. (C) Graphical representation of the population of granulocytic cells labeled with CH138-APC (FL4 emitted at a wavelength of $661 \pm 16 \mathrm{~nm}$ ). (D) Histogram of CD14+ cells that phagocytosed Staphylococcus aureus + propidium iodide (FL3 emitted at a wavelength of $670 \mathrm{~nm}$ ). (E) Histogram of CH138+ cells that produced dichlorofluorescein (DCFH; FL1 emitted at a wavelength of $530 \pm 30 \mathrm{~nm}$ ). (F) Histogram of CH138+ cells that phagocytosed Escherichia coli + propidium iodide (FL3 emitted at a wavelength of $670 \mathrm{~nm}$ ). Color version available online. 
Similar results were observed in the assays measuring the phagocytosis of $E$. coli by the CD14+ and CH138+ cells. The percentage of phagocytosis by the CD14+ cells during M1 was higher than that during M4, M5, M6, and M7. In turn, a higher percentage of phagocytosis occurred during M3 than during M4 ( $P$ $=0.0004)$, but no difference was observed for the other age intervals. The mean phagocytosis values showed a significant difference with age, with lower phagocytic intensity during M3 than during M7 $(P=0.0202)$.

A greater percentage of phagocytosis by the CH138+ cells (Figure 1E) was observed during M1 than during M5 and M8, and M2 showed a higher percentage of phagocytosis than that occurring during M8 $(P=$ $0.0025)$. Such differences were not observed between the other age intervals, corroborating Menge et al. (1998), who noted a greater capacity to phagocytose E. coli in older animals. The mean values for the phagocytic intensity $(P=0.1395)$ did not differ statistically among the age intervals. Positive and strong correlations between the percentage of phagocytosis of $S$. aureus and $E$. coli in both populations (Pearson $\mathrm{r}=0.9226, P$ $=0.0011$ for the population of CD14+; Pearson $\mathrm{r}=$ $0.7079, P=0.0495$ for the population of $\mathrm{CH} 138+$ ) were also observed, reiterating the reported results.
The DCFH-DA was used to assess the oxidative activity of blood phagocytes. The fluorescence produced by DCFH-DA is directly proportional to the oxidative metabolic activity and is apparently mediated by $\mathrm{H}_{2} \mathrm{O}_{2}$ (Hirabayashi et al., 1985; Kobzik et al., 1990). Thus, using flow cytometry, the DCFH-DA assay may enable the quantification of oxidative activity (ROS production) in individual cells by measuring the fluorescence of each (Bass et al., 1983; Kobzik et al., 1990; Figure 1D).

We observed that a higher percentage of intracellular ROS production by CD14+ monocytic cells occurred during M2 than during M5 $(P=0.0221)$. However, the fluorescence intensity showed no significant difference over time $(P=0.3520)$. Although no significant difference was shown, the performance of monocytic cells over time showed that the MFI values for ROS production decreased until $30 \mathrm{~d}$ of age, increased at approximately $45 \mathrm{~d}$ of age, and then sharply dropped at $90 \mathrm{~d}$ of age, corroborating the results found for the phagocytosis of $S$. aureus conjugated to PI.

The intracellular production of ROS by the $\mathrm{CH} 138+$ cells $(P=0.1859)$ showed no differences among the collection times, and no difference was noted in the MFI. However, both the production and the MFI decreased

Table 1. Percentage values (means \pm SE) for monocytic cells, frequency of CD14+ monocytic cells, intracellular reactive oxygen species production (dichlorofluorescein; $\mathrm{DCFH}^{+}$) and Staphylococcus aureus and Escherichia coli phagocytosis and their respective mean fluorescence intensities (MFI), expressed as arbitrary values in blood taken from healthy calves during the first 3 mo of life

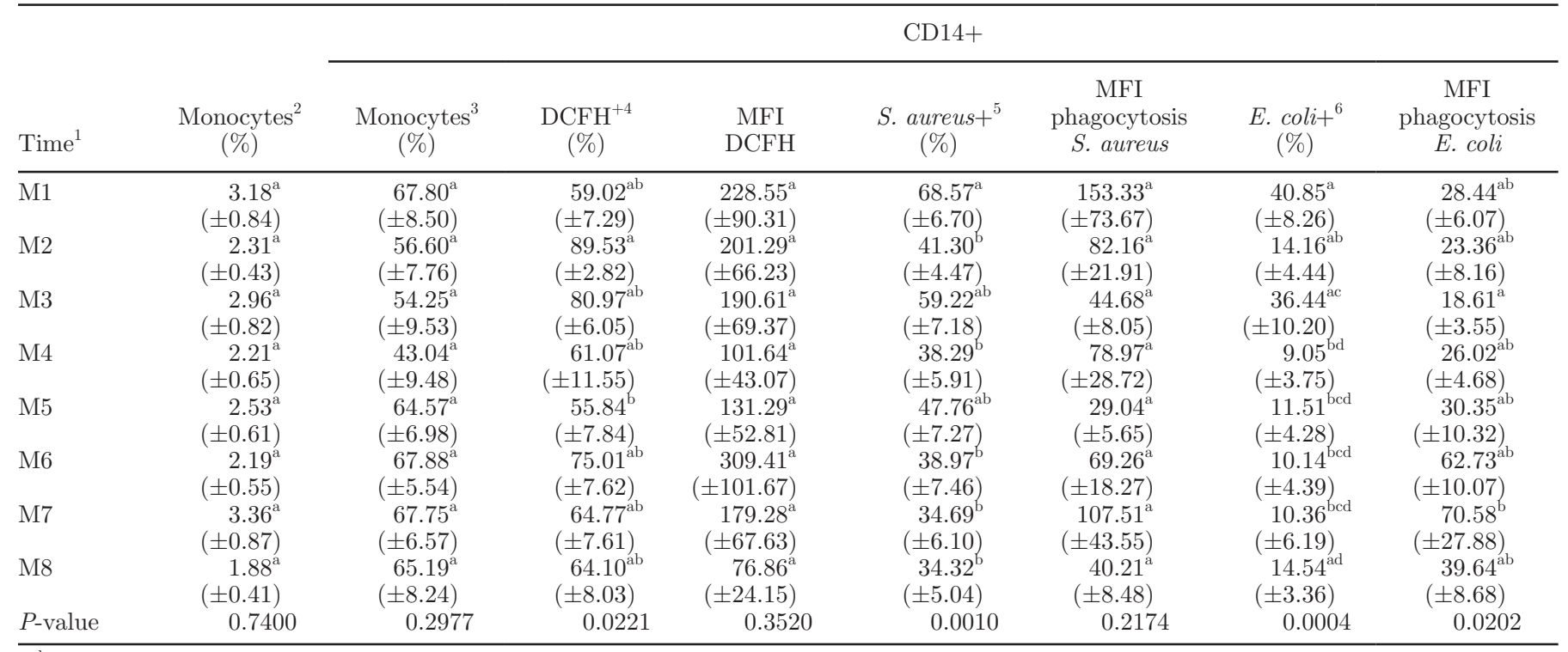

\footnotetext{
${ }^{\mathrm{a}-\mathrm{d}}$ Different letters indicate significant differences between the experimental times $(P<0.05)$. (M7), and $90 \mathrm{~d}$ old (M8).

${ }^{2}$ The column labeled monocytes cells is the percentage of monocytes in the total population of blood leukocytes.

${ }^{3} \mathrm{CD} 14+/$ Monocytes $=$ cells expressing CD14 in the total population of blood monocytes.

${ }^{4} \mathrm{CD} 14+/ \mathrm{DCFH}^{+}=$cells expressing $\mathrm{CD} 14$ that produced reactive oxygen species.

${ }^{5} \mathrm{CD} 14+/ S$. aureus $+=$ cells expressing CD14 that phagocytosed $S$. aureus.

${ }^{6} \mathrm{CD} 14+/ E$. coli $+=$ cells expressing CD14 that phagocytosed E. coli.
}

${ }^{1}$ First week of life (M1), 8 to $14 \mathrm{~d}$ old (M2), 15 to $22 \mathrm{~d}$ old (M3), 23 to $30 \mathrm{~d}$ old (M4), 31 to $40 \mathrm{~d}$ old (M5), 41 to $50 \mathrm{~d}$ old (M6), 51 to $60 \mathrm{~d}$ old 
numerically, as reported by Menge et al. (1998), who found a higher percentage of ROS production by neutrophils in newborn animals.

Tables 1 and 2 outline the mean percentages $( \pm$ standard errors) of the CD14+ monocytic cells and the CH138+ granulocytic cells, respectively, from the blood samples as well as their intracellular ROS production percentage and fluorescence intensity values. These cells phagocytosed $S$. aureus and E. coli stained with PI, demonstrating that the reduction of innate immune cell activity is apparently more pronounced between 40 and $50 \mathrm{~d}$ of age. Thus, stress factors such as transport, vaccinations, dehorning, castration, and facility changes should be avoided during that critical period of immunity maturation (Nonnecke et al., 2009), because stress is known to affect the innate and adaptive immune responses in young and adult animals (Cortese, 2009).

However, it is exactly at this time that calves are weaned when there is a greater dependence on the active immune response. The weaning of dairy calves is based on the ability to eat solid food, which occurs at approximately 50 to $60 \mathrm{~d}$ of age. Researchers are concerned with establishing methods to reduce wean- ing stress, although they fail to speculate on whether the calves are immunologically immature at this time (Bach et al., 2010; De Paula Vieira et al., 2010; Vasseur et al., 2010).

\section{CONCLUSIONS}

Variation exists with age in the innate immune function of healthy calves and there is apparently an increased susceptibility to disease from $40 \mathrm{~d}$ of life, an age at which fewer phagocytes are active, although those that are active perform their role with greater efficiency than is shown by the phagocytes present during the first weeks of life. This pattern persists, albeit less remarkably, until $90 \mathrm{~d}$ of age, when animals have not yet attained the stability needed to complete the maturation of the innate immune response.

\section{ACKNOWLEDGMENTS}

The authors are grateful for the financial support of the São Paulo State Research Foundation (São Paulo, Brazil; Project number 2009/06013-1).

Table 2. Percentage values (means \pm SE) for granulocytic cells, frequency of CH138+ granulocytes, intracellular reactive oxygen species production (dichlorofluorescein; $\mathrm{DCFH}^{+}$) and Staphylococcus aureus and Escherichia coli phagocytosis and their respective mean fluorescence intensities (MFI), expressed as arbitrary values in blood taken from healthy calves during the first 3 mo of life

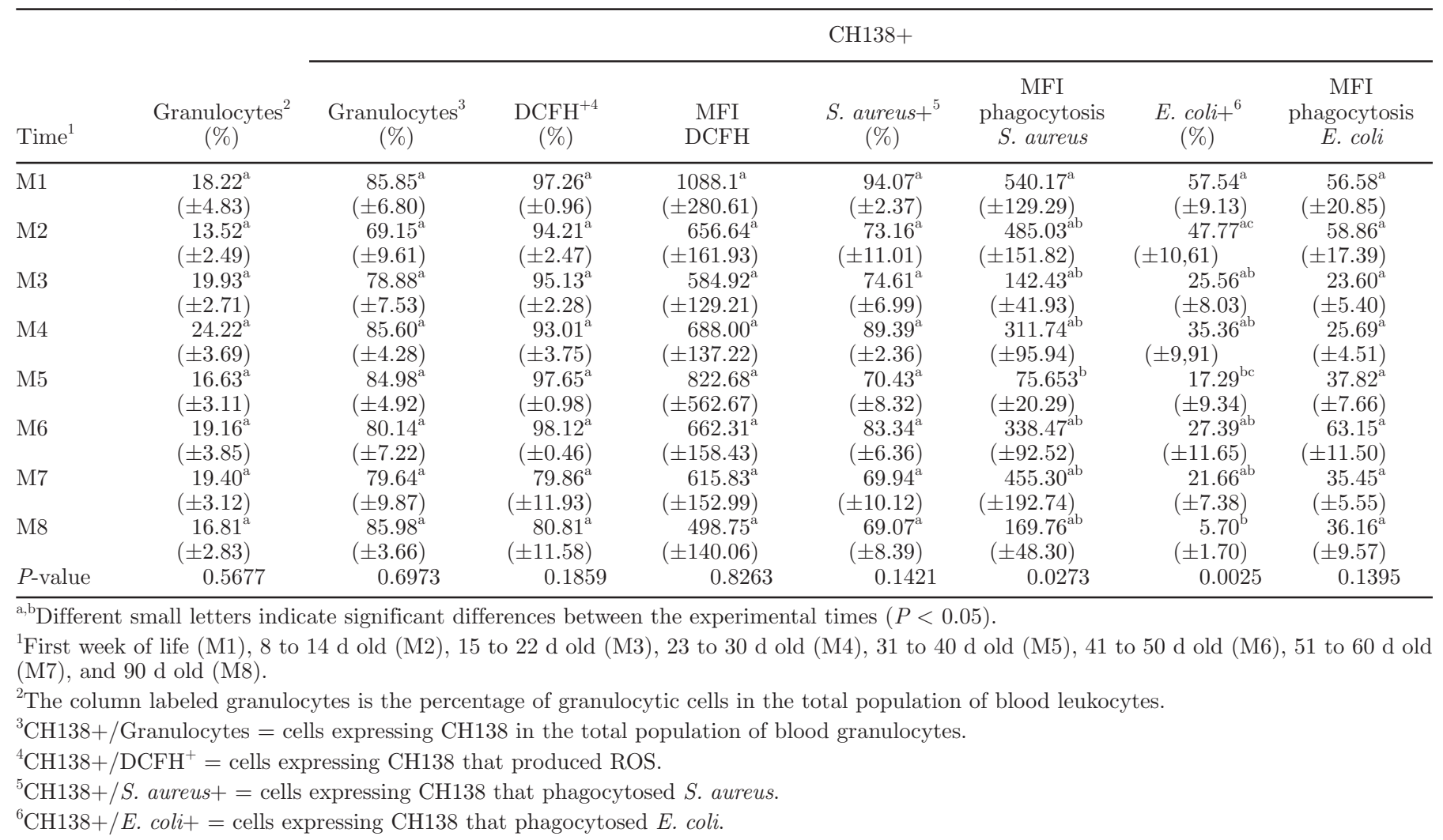




\section{REFERENCES}

Ackermann, M. R., R. Derscheid, and J. A. Roth. 2010. Innate immunology of bovine respiratory disease. Vet. Clin. North Am. Food Anim. Pract. 26:215-228.

Bach, A., J. Ahedo, and A. Ferrer. 2010. Optimizing weaning strategies of dairy replacement calves. J. Dairy Sci. 93:413-419.

Barrington, G. M., and S. M. Parish. 2001. Bovine neonatal immunology. Vet. Clin. North Am. Food Anim. Pract. 17:463-476.

Bass, D. A., J. W. Parce, L. R. Dechatelet, P. Szejda, M. C. Seeds, and M. Thomas. 1983. Flow Cytometric studies of oxidative product formation by neutrophils: A graded response to membrane stimulation. J. Immunol. 130:1910-1917.

Batista, C. F., M. G. Blagitz, B. P. Santos, H. P. Bertagnon, A. C Parra, R. S. Vianna, G. G. de Lucca, D. M. Lima, D. S. Santos, and A. M. Della Libera. 2012. Maturation of mononuclear phagocytes in the lungs of young calves - In vitro study. J. Dairy Sci. 95:5909-5915.

Benesi, F. J. 1993. Síndrome asfixia neonatal dos bezerros. Arq. Esc. Med. Vet. Univ. Fed. Bahia 16:38-48.

Chase, C. C. L., D. J. Hurley, and A. J. Reber. 2008. Neonatal immune development in the calf and its impact on vaccine response. Vet. Clin. North Am. Food Anim. Pract. 24:87-104.

Coelho, S. G. 2009. Desafios Na Criação E Saúde de Bezerros. Ciên. Anim. Bras. Suppl. 1:1-18.

Cortese, V. S. 2009. Neonatal immunology. Vet. Clin. North Am. Food Anim. Pract. 25:221-227.

De Paula Vieira, A., M. A. G. von Keyserlingk, and D. M. Weary 2010. Effects of pair versus single housing on performance and behavior of dairy calves before and after weaning from milk. J. Dairy Sci. 93:3079-3085.

Feitosa, F. L., E. H. Birgel, R. M. S. Mirandola, and S. H. V. Perri. 2001. Diagnóstico de falha de transferência de imunidade passiva em bezerros através da determinação de proteína total e de suas frações eletroforéticas, imunoglobulinas G E M E da atividade da gama glutamil transferase no soro sanguíneo. Ciência Rural $31: 251-255$.

Feitosa, F. L. F. 2010. Índices de falha de transferência de imunidade passiva (FTIP) em bezerros holandeses e nelores, às 24 e 48 horas de vida: valores de proteína total, de gamaglobulina, de imunoglobulina G E Da atividade sérica de gama glutamil transferase, para o diagnósti. Pesqui. Vet. Bras. 30:696-704.

Hasui, M., Y. Hirabayashi, and Y. Kobayashi. 1989. Simultaneous measurement by flow cytometry of phagocytosis and hydrogen peroxide production of neutrophils in whole blood. J. Immunol. Methods 117:53-58

Hirabayashi, Y., S. Taniuchi, and Y. Kobayashi. 1985. A quantitative assay of oxidative metabolism by neutrophils in whole blood using flow cytometry. J. Immunol. Methods 82:253-259.

Hussen, J., A. Düvel, O. Sandra, D. Smith, I. M. Sheldon, P. Ziegler, and H. J. Schuberth., 2013. Phenotypic and functional heterogeneity of bovine blood monocytes. PLoS ONE 8:e71502.

Kampen, A. H., I. Olsen, T. Tollersrud, A. K. Storset, and A. Lund 2006. Lymphocyte subpopulations and neutrophil function in calves during the first 6 months of life. Vet. Immunol. Immunopathol. 113:53-63.

Kampen, A. H., T. Tollersrud, S. Larsen, J. A. Roth, D. E. Frank, and A. Lund. 2004a. Repeatability of flow cytometric and classical measurement of phagocytosis and respiratory burst in bovine polymorphonuclear leukocytes. Vet. Immunol. Immunopathol. 97:105-114.
Kampen, A. H., T. Tollersrud, and A. Lund. 2004b. Flow cytometric measurement of neutrophil respiratory burst in whole bovine blood using live Staphylococcus aureus. J. Immunol. Methods 289:47-55.

Kobzik, L., J. J. Godleski, and J. D. Brain. 1990. Selective downregulation of alveolar macrophage oxidative response to opsoninindependent phagocytosis. J. Immunol. 144:4312-4319.

Koterba, A. M. 1993. Identificação do neonato de alto risco. Distúrbios e tratamento do neonato. Pages 299-301 in Tratado de Medicina Interna de Grandes Animais. B. P. Smith, ed. Manole, São Paulo, Brazil.

Machugh, D. E., M. Taraktsoglou, K. E. Killick, N. C. Nalpas, J. A. Browne, S. D. E. Park, K. Hokamp, E. Gormley, and D. A. Magee. 2012. Pan-genomic analysis of bovine monocyte-derived macrophage gene expression in response to in vitro infection with Mycobacterium avium subspecies paratuberculosis. Vet. Res. 43:25.

Menge, C., B. Neufeld, W. Hirt, N. Schmeer, R. Bauerfeind, G. Baljer, and L. H. Wieler. 1998. Compensation of preliminary blood phagocyte immaturity in the newborn calf. Vet. Immunol. Immunopathol. 62:309-321.

Morein, B., I. Abusugra, and G. Blomqvist. 2002. Immunity in neonates. Vet. Immunol. Immunopathol. 87:207-213.

Nauseef, W. M., and R. Clark. 2015. Granulocytic phagocytes. Pages 78-92 in Mandell, Douglas, and Bennett's Principles and Practice of Infectious Diseases. G. L. Mandell, J. E. Bennett, and R. Dolin, ed. Churchill Livingstone, Philadelphia, PA.

Nonnecke, B. J., M. R. Foote, B. L. Miller, M. Fowler, T. E. Johnson, and R. L. Horst. 2009. Effects of chronic environmental cold on growth, health, and select metabolic and immunologic responses of preruminant calves. J. Dairy Sci. 92:6134-6143.

Paape, M. J., D. D. Bannerman, X. Zhao, and J. W. Lee. 2003. The bovine neutrophil: Structure and function in blood and milk. Vet. Res. 34:597-627.

Perticarari, S., G. Presani, and E. Banfi. 1994. A new flow cytometric assay for the evaluation of phagocytosis and the oxidative burst in whole blood. J. Immunol. Methods 170:117-124

Peixoto, A. P. C.. J. N. Costa, A. Kohayagawa, R. K. Takahira, and M. E. Saito. 2002. Hemograma e metabolismo oxidativo dos neutrófilos de bovinos da raça holandesa preta e branca-Influência dos fatores etários. Rev. Bras. Saúde. Prod. Anim. 3:16-20.

Raidal, S. L., G. D. Bailey, and D. N. Love. 1998. Flow cytometric determination of oxidative burst activity of equine peripheral blood and bronchoalveolar lavage-derived leucocytes. Vet. J. 156:117126.

Souza, F. N. D. 2012. Intracellular reactive oxygen species production by polymorphonuclear leukocytes in bovine leukemia virus-infected dairy cows. J. Vet. Med. Sci. 74:221-225.

Stieler, A., B. S. Bernardo, and G. A. Donovan. 2012. Neutrophil and monocyte function in neonatal dairy calves fed fresh or frozen colostrum. Intern. J. Appl. Res. Vet. Med. 10:328-334.

Taraktsoglou, M. 2011. Transcriptional profiling of immune genes in bovine monocyte-derived macrophages exposed to bacterial antigens. Vet. Immunol. Immunopathol. 140:130-139.

Tizard, I. R. 2012. Veterinary Immunology: An Introduction. 8th ed. I. R. Tizard, ed. Elsevier, St. Louis, MO.

Underhill, D. M., and A. Ozinsky. 2002. Phagocytosis of microbes: Complexity in action. Annu. Rev. Immunol. 20:825-852.

Vasseur, E. 2010. A survey of dairy calf management practices in canada that affect animal welfare. J. Dairy Sci. 93:1307-1315.

Windeyer, M. C. 2014. Factors associated with morbidity, mortality, and growth of dairy heifer calves up to 3 months of age. Prev. Vet. Med. 113:231-240. 